\title{
EVALUATING ORGANIZATIONAL CHARACTERISTICS COMPLEMENTARY WITH ENTERPRISE SOFTWARE PRODUCTS
}

\author{
Tomaž HOVELJA (D) 1 , Olegas VASILECAS (D) ${ }^{2}$, Diana KALIBATIENE் (D) ${ }^{*}$, \\ Rok RUPNIK ${ }^{\text {(D) }} 4$ \\ 1, ${ }^{4}$ Faculty of Computer and Information Science, University of Ljubljana, \\ Ljubljana, Slovenia \\ 2, 3 Information Systems Department, Faculty of Fundamental Sciences, \\ Vilnius Gediminas Technical University, Vilnius, Lithuania
}

Received 29 August 2019; accepted 09 March 2020

\begin{abstract}
Implementation, deployment and maintenance of enterprise software pre-configured products are one of the key challenges managers need to address in order to stay competitive in the never ending search to find better ways of conducting business. In the literature there are discovered two general approaches through which managers can use for a successful implementation, deployment and maintenance of enterprise software products. First approach is based on the internal re-deployment of the managerial practices that are already used to manage other fields in the enterprise. Second - the deployment of "world-wide" industry "best practices" that international vendors of enterprise software and their local representatives sell as part of their pre-configured software products. This paper presents a novel model that enables enterprises to systematically evaluate the fit between their specific organizational characteristics and the organizational characteristics complementary with successful deployment of international pre-configured enterprise software products. The proposed model is tested through a comparison of two groups of enter-prises from the population of 1000 biggest enterprises in Slovenia. The first group mostly invests in local, while the second group mostly invests in international enterprise software products. The paper finds that on average there are significant and relevant differences in $44 \%$ of the examined organizational characteristics between the groups of enterprises that mostly invest in international or local enterprise software products. The model serves as a comprehensive organizational risk checklist for enterprises that are about to invest in enterprise software products.
\end{abstract}

Keywords: enterprise software investments, international enterprise software products, local enterprise software products, organizational characteristics, software products, pre-configured software products.

JEL Classification: M21, G11, G19.

*Corresponding author. E-mail: diana.kalibatiene@vgtu.lt

This is an Open Access article distributed under the terms of the Creative Commons Attribution License (http://creativecommons. org/licenses/by/4.0/), which permits unrestricted use, distribution, and reproduction in any medium, provided the original author and source are credited. 


\section{Introduction}

The effects of wide use of IT as a general purpose technology in enterprises can only be compared to the effects the steam engine and electrical motor had on the creation of goods (Bresnahan, 2003). As a consequence, implementation, deployment and maintenance of enterprise software pre-configured products are one of the key challenges managers need to address in order to stay competitive in the never ending search to find better ways of conducting business (Bartel et al., 2007; Basu \& Fernald, 2007; Dedrick et al., 2013; Kleis et al., 2012; Rezende da Costa et al., 2018; de Santana et al., 2018; Neubert \& Van der Krogt, 2018; Potluri \& Vajjhala, 2018). The enterprise software pre-configured products that most often support business related tasks and processes are Enterprise Resource Planning (ERP), Supplay Chain Management (SCM), Customer Relationship Management (CRM), Business Intelligence (BI), and Big Data Analytics (BDA) (Gronwald, 2017). The international literature describes two general approaches which managers can use for a successful implementation, deployment and maintenance of enterprise software products (Markus \& Tanis, 2000; Shafique et al., 2019; Davidavičiene et al., 2018). First approach is based on the internal re-deployment of the managerial practices that are already used to manage other fields in the enterprise. Second approach, favored by the literature and the big international IT vendors (Markus \& Tanis, 2000; Howcroft \& Light, 2006; Microsoft Corporation, 2008, 2015, 2017; Oracle Corporation, 2008, 2013, 2017; SAP AG, 2008; SAP SE, 2015; Potluri \& Vajjhala, 2018), is based on the deployment of "world-wide" industry "best practices" that international vendors of enterprise software and their local representatives sell as part of their pre-configured software products. Based on various empirical evidence published in the last decade one can't but acknowledge the success of big international vendors; the deployment of worldwide industry best practices integrated into international pre-configured enterprise software products established itself as the dominant way enterprises invest in IT in the world in general (Batenburg et al., 2006; Shaul \& Tauber, 2013; Romero \& Martínez-Román, 2015) as well as in Slovenia in particular (Slovenian Chamber of Commerce, 2004; Hovelja, 2008).

Researchers adjusted to the above mentioned development in the field by focusing their research on empirical analysis of the success of investments of pre-configured enterprise software products in the international markets and on the challenge of improving their deployment in terms of speed, cost and quality (Moon, 2007; Sudhaman \& Thangavel, 2015). Despite all this focus and deployment failure rates, which remained higher than $50 \%$ in the last 15 years (Goyettea et al., 2014; Shaul \& Tauber, 2013), the majority of research reports (Chen et al., 2018) show a positive relationship among the IT investment and the company's productivity and market value. The majority of cited research is however done in the USA, were the dominant international enterprise software vendors such as Microsoft, SAP, Oracle with their business partners also conduct the majority of their research on identifying the "best worldwide industry practices" (Microsoft Corporation, 2008; Oracle Corporation, 2008). Even SAP, as the only major non-American enterprise IT vendor, uses Fortune 500 companies as important key business partners in the development of its ERP product of "best practices" (SAP, 2004). These "best practices" are then augmented with local best practices designed to address local business customs (SAP, 2008). Thus one can objectively conclude 
that most of "universal or worldwide industry best practices" actually originate from North America and to some extent Germany (Heinzelmann, 2017). Most of the published empirical research on the usefulness of these practices (Moon, 2007) and how ICT (Information and Communication Technology) investments contribute to enterprise's productivity (Liao et al., 2016) were likewise conducted in USA.

This paper advances the notion that the claim of worldwide or universal usefulness of the above described industry best practices incorporated into pre-configured enterprise software is empirically not yet sufficiently proven outside their countries of origin (Soh et al., 2000; Kyung-Kwon \& Young-Gul, 2002; Hawking, 2007). Such position is in line with research that analyzed different factors of successful implementation of ERP and other technologies in different countries, like in Jordan (Mohammad, 2018), United Kingdom (Jayawickrama et al., 2017), India (Saravanan \& Sundar, 2015), and domain areas, like in hospital (Garg \& Agarwal, 2014), etc. For this reason, we do not refer to these best practices as universal or worldwide but as international pre-configured "best practices", since they are sold by dominant international IT vendors (Shaul \& Tauber, 2013).

Based on the presented arguments one could reasonably claim that these best practices, are actually standard American and to a lesser extent German management practices used by their different industries. If one considers research findings on international effectiveness of general management practices in the last decades (Hofstede, 1980, 2003), the ability of these management practices to cross national borders without losing effectiveness and efficiency is questionable at best.

To gain new insights into the success of investments in enterprise software products, specifically the success of investments in international pre-configured enterprise software products outside of their countries of origin this paper compares the success of investments in enterprise software products for two groups of enterprises in Slovenia. One that invests in local pre-configured enterprise software products and one that invests in international preconfigured enterprise software products.

Such comparison can help us answer the following research questions:

RQ1: What organizational characteristics, if any, need to be deployed by the enterprises in order to improve the success of investments in international enterprise software products?

RQ2: Are there important organizational differences between enterprises that predominantly invest in international enterprise software products and enterprises that predominantly invest in local enterprise software products?

RQ3: Do investments in international enterprise software products deliver higher productivity growth compared to investments in local enterprise software products?

RQ4: Does the proposed approach for evaluating the risk of success/failure of the investment in international enterprise software products provide non-trivial information to enterprises?

To answer the above stated research questions the paper is organized as follows. The theoretical background section deals with the review of key literature from the studied area, needed to adequately address RQ1 and identify what type of organizational characteristics are needed to successfully use international enterprise software products. Based on this review the second section presents a new approach for evaluating the risk of investment in interna- 
tional pre-configured enterprise software products. In the third section the paper presents the methodology and sample selection procedures of the empirical research that was done on the population of 1000 biggest enterprises in Slovenia. In the fourth section the results of the empirical study are presented. The fifth section discusses the key results from the perspective of the paper's research questions. The sixth section concludes the paper.

\section{Theoretical background}

The study of management of IT investments in enterprises has a long, well documented and well established history in the literature, with American researchers usually leading the way. The field gained prominence with the first studies of the productivity of the use of IT in the late eighties. These studies are best summarized with a saying attributed to Robert Solow: "We see computers everywhere but in the productivity statistics" (Paul, 1990). The resolutions of the major methodological issues through the nineties helped solve this IT productivity paradox at the turn of the century. Several very prominent studies showed how the use of IT affects enterprises' productivity and how IT was a major factor behind the global productivity growth since the early nineties (Basu \& Fernald, 2007; Daveri, 2004; Inklaar et al., 2003; Mittal \& Nault, 2009; OECD, 2004; Mithas \& Rust, 2016). Nowadays, also a number of studies present methods of adopting different ERP systems in Small and Medium Sized Enterprises (SMEs), like Software as a Service (SaaS) in Seethamraju (2015), and assessing ERP postimplementation success in Hsu et al. (2015). The cited studies also formed the hypothesis that without appropriate management of IT investments in the enterprise the productivity benefits of the use of IT are low (if present at all). The hypothesis that mismanagement of IT in enterprises is one of the key organizational issues of today's management of course had/ has its critics.

To explore the stated research questions, the paper proposes an approach for evaluating the fit between a specific enterprise and its organization and the required/complementary organizational characteristics for/with successful investments in international enterprise software products. However, before a new approach can be proposed, the review of the related works needs to answer the first research question (RQ1). RQ1 asks which organizational characteristics of the enterprise, if any, need to be deployed by the enterprise to improve the success of investments in international enterprise software products? In Table 1 the organizational characteristics that positively influence the success of investments in enterprise software products in USA are presented. Since US is the biggest market of international enterprise software vendors, where they (SAP, Oracle, Microsoft) have a dominant market position, we can state that the organizational characteristics identified as required for/complementary with successful investments in enterprise software products in USA (Table 1) are the ones that improve the success of investments in international enterprise software worldwide.

The above presented organizational characteristics generally fit well with successful investments in international software products because they facilitate the implementation of significant changes to the business and management related tasks and practices through the entire enterprises's value chain (Tagliavini et al., 2001) from R\&D (technological research, product development...), through HRM (Recruitment, Training...), Production (Product 
Table 1. Required/complementary organizational characteristics for successful investments in enterprise software products (ERP, CRM, ...) in USA

\begin{tabular}{|l|l|l|}
\hline \multicolumn{1}{|c|}{$\begin{array}{c}\text { Organizational } \\
\text { dimensions }\end{array}$} & \multicolumn{1}{|c|}{ Organizational characteristics } & \multicolumn{1}{c|}{ Sources } \\
\hline $\begin{array}{l}\text { Cultural } \\
\text { characteristics of } \\
\text { enterprise }\end{array}$ & $\begin{array}{l}\text { Increasing the support employees } \\
\text { receive from superiors, increasing } \\
\text { the commitment of the employees, } \\
\text { improved innovativeness, improved } \\
\text { control, improved continuous learning }\end{array}$ & $\begin{array}{l}\text { Brown \& Leigh, 1996; Denison, 1997; } \\
\text { Baker, 2002; Neal et al., 2000; Poku } \\
\text { \& Vlosky, 2002; Delobbe et al., 2002; } \\
\text { Cameron, 2008; Ke \& Wei, 2008. }\end{array}$ \\
\hline $\begin{array}{l}\text { Strategical } \\
\text { characteristics of } \\
\text { enterprise }\end{array}$ & $\begin{array}{l}\text { Improving the sophistication of } \\
\text { strategic planning/knowledge } \\
\text { management, improving cost } \\
\text { leadership, improving product } \\
\text { differentiation, increasing the use } \\
\text { of inter organisational synergies, } \\
\text { increasing bargaining power in the } \\
\text { supply chain }\end{array}$ & $\begin{array}{l}\text { Porter \& Millar, 1985; Bakos } \\
\text { \& Treacy, 1986; Henderson \& } \\
\text { Venkatraman, 1999; Kettinger et al., } \\
\text { 1994; Gupta et al., 1997; Hedman } \\
\text { \& Kalling, 2001; Garg et al., 2002; } \\
\text { Bergeron et al., 2002; Ko et al., 2008. }\end{array}$ \\
\hline $\begin{array}{l}\text { Structural } \\
\text { characteristics of } \\
\text { enterprise }\end{array}$ & $\begin{array}{l}\text { Decreasing centralisation, increasing } \\
\text { group/team based method of } \\
\text { work, decreasing formalisation, } \\
\text { decreasing vertical differentiation, } \\
\text { decreasing specialisation, increasing } \\
\text { professionalization, increasing goal } \\
\text { oriented remuneration system, } \\
\text { increasing communication with the } \\
\text { environment }\end{array}$ & $\begin{array}{l}\text { Damanpour, 1991; Hammer \& } \\
\text { Champy, 1993; Grover \& Goslar, } \\
\text { 1993; Swanson, 1994; Fichman } \\
\text { \& Kemerer, 1997; Fiedler et al., } \\
\text { 1996, Fichman, 2000; Dewett \& } \\
\text { Jones, 2001; Bergeron et al., 2002; } \\
\text { Brynjolfsson et al., 2002; Morton \& } \\
\text { Hu, 2008. }\end{array}$ \\
\hline
\end{tabular}

planning, Maintenance...), Logistics (Inventory management, Delivery of products...), Marketing and Sales (Advertising, After sale service...) to Infrastructure Activities (Financial management, Legal service...). These same organizational characteristics are on the other hand not required to facilitate investments in local enterprise software products, since the local enterprise software products fit the existing business and management related tasks and practices of local enterprises significantly better than the international ones. Hence the existing internal business and managerial practices of the value chain do not need to be changed considerably or at all when implementing local software, thereby shifting the focus of the implementation of local software products from organizational transformation to automation and informatization (Bresnahan, 2001).

On a theoretical level the identified organizational characteristics help advance the enterprise software risk implementation literature. Several risk models already point out that strategical, cultural and structural characteristics of the enterprise which facilitate organizational transformation are one of the most important sources of risks and thus critical success factors of successful deployment (Scott \& Vessey, 2002; Yusuf et al., 2004; Ehie \& Madsen, 2005; Aloini et al., 2007; Hakim \& Hakim, 2010; Dey et al., 2013). However they mostly stop at the level of the organizational dimension itself (i.e. poor understanding of corporate culture, poor strategic vision, poor organizational structure) and don't focus on identification of specific organizational characteristics of an organizational dimension that are the actual risk factors. Thus our model can be of significant benefit to well established 
risk management frameworks such as PRINCE2, PMBOK, the Australian Standard and the General Risk Management Framework (Aloini et al., 2012) with the timely identification of specific organizational risk factors in the risk assessment stage.

Additionally, the identified organizational characteristics can be used by multi-criteria decision-making (MCDM) approaches for ERP system selection if the MCDM approach in addition to the quantitative criteria also considers qualitative criteria (Temur \& Bolat, 2018), e.g., Fuzzy analytic network process approach, Fuzzy quality function deployment approach, Fuzzy data envelopment analysis approach and other fuzzy or combined approaches (Brzozowski \& Birfer, 2017; Hornos \& Herrera-Viedma, 2018). In Zeng et al. (2017) authors propose a model to select an ERP system for Chinese small- and medium-sized enterprises. Integrating our qualitative evaluation of organizational characteristics in existing MCDM approaches shouldn't prove difficult, since in the last decades fuzzy derivatives of the classis approaches or combinations between fuzzy and non-fuzzy aproaches have been favored over the original more quantitative approaches (Enea \& Piazza, 2004; Mohanty et al., 2005; Junior et al., 2014; Brzozowski \& Birfer, 2017).

\section{Proposed approach}

The proposed approach for evaluating the success of the international enterprise software products is a process approach. As such it is in line with the literature recommendation of modelling IT deployment as a process instead of using a »black box « variance approach (Kohli \& Sherer, 2002). The process approach requires that we first analyse the fit between the existing organizational characteristics of an enterprise and the pre-configured international enterprise software products (Haddara, 2014). Only then should one analyse the impact enterprise software products have on the success of enterprises. Such an approach will enable us to understand if the actual organisational characteristics match the organizational characteristics of enterprises that successfully use international pre-configured software products in USA and Germany. This will enable us to understand if there are general issues with the success of such investments or the issues only arise when there is a lack of fit between the required and actual organizational characteristics of an enterprise. To gain these insights the proposed approach presented in Figure 1 first forms two groups of enterprises based on their decision to pre-dominantly invest in pre-configured international enterprise software products or local enterprise software products. Then it compares these two groups in two stages. In the first stage the approach compares the cultural, strategical and structural organizational characteristics of the two groups against each other as well as against the key (complementary) organizational characteristics that are according to the literature required for productive use of international pre-packaged software products in US enterprises. In the second stage the approach then compares how successfully enterprises in each group are at translating investments in enterprise software products into economic success. Such a process approach follows the guidelines that good socio-technical models should consider (Kling \& Lamb, 2000), builds on the knowledge of multiple iterations of Levitt and Scott-Morton models (Gimenez \& Suarez, 2004) as well as on the knowledge of the Interaction model (Beath et al., 1995) and IT Business Value model (Gurbaxani et al., 2004). 


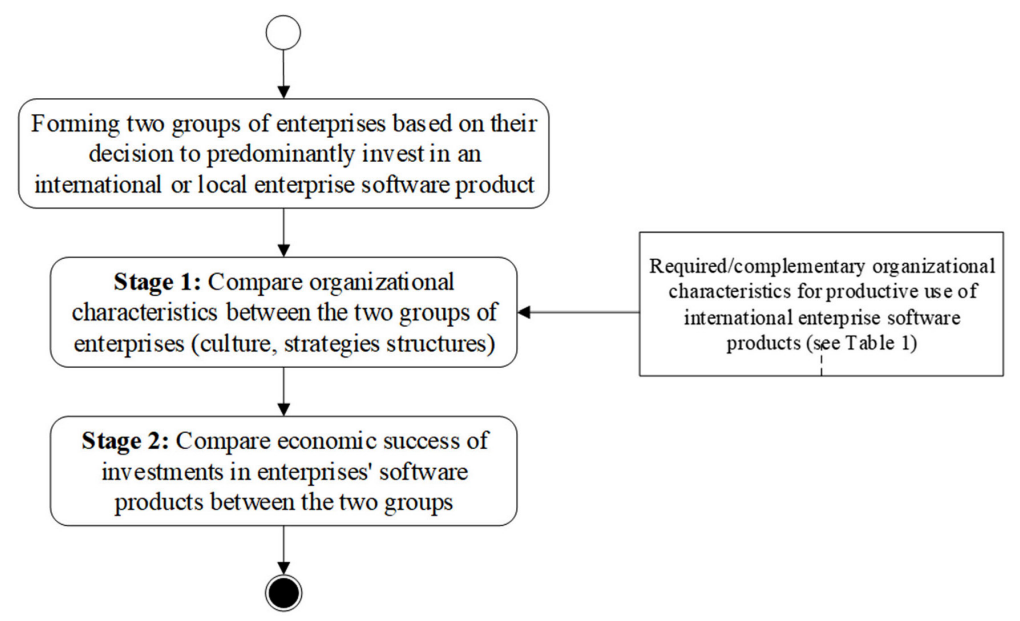

Figure 1. The proposed approach for evaluation of the success of the investments in enterprise software products (ERP, CRM, ...)

\section{Method}

In this section we address the methodology used to conduct the empirical test of the proposed model. Methodology is split into the three sections that address different methodological issues: survey preparation, method selection and survey execution.

\subsection{Survey preparation}

To answer the defined research questions of the paper the survey had to gather the data on the variables presented in Figure 1. Thus the survey had to collect the data if enterprises invest into local or international enterprise software products, the data on cultural, strategic and structural characteristics of enterprises and the data on different dimension of economic success of IT investments (IT use, added value per employee...). To collect the data about the type of enterprise software products enterprises invest in and their cultural, strategic and structural characteristic that influence the success of the investments in enterprise software products five point Likert scales (strongly agree, agree, neither agree nor disagree, disagree and strongly disagree) were used, because of their conceptual unambiguousness and widespread use. Other preparations of the survey can be found in (Hovelja et al., 2013).

\subsection{Method selection}

In accordance with the proposed approach and to answer the second research question (RQ2) which requires a comparison of enterprises that predominantly invest in international software products with those that predominantly invest in local software products a 2 level categorical variable with each level representing one of these two groups of enterprises needs to be established. This categorical variable was defined by recoding the 5 point Likert scale that measured the survey respondents agreement (from strongly agree to strongly disagree) 
with the statement that their enterprise invests predominantly into international pre-configured software products. Its Likert values of 1 and 2 were recoded to represent the group of 25 enterprises that predominantly invest in local software products while the Likert values of 4 and 5 were recoded to represent the group of 24 enterprises that predominantly invest in international enterprise software products. The remaining 45 enterprises in the sample were unable to choose which enterprise software investment strategy they predominantly follow. By being strategically "stuck in the middle" their analysis didn't contribute greatly towards addressing the posed research questions. For this reason they were not included in the recoded 2 level categorical variable that was the basis for statistical comparison of organizational, economic and IT use characteristics between the group of enterprises that invest predominantly in local enterprise software products and the group of enterprises that invest predominantly in international enterprise software products. The 2 level categorical variable representing the two groups of enterprises that are of interest for the analysis can function as the only dependant variable for our chosen statistical method and all other variables can function as independent scale variables with distributions (skewness, kurtosis) that do not greatly differ from normality, which would make parametric testing problematic (Ozgur \& Strasser, 2004; Barrett et al., 2005).

In situations with one 2 level categorical dependent variable and several scale independent variables the recommended statistical method of analysis is discriminant analysis (Barret et al., 2005). However it is generally best to have 4 or 5 times as many observations as independent variables for the discriminant analysis (Barfield et al., 2004). The size of the sample presented in this paper compared to the amount of independent variables analyzed unfortunately doesn't meet this requirement; hence instead of using a single multivariate analysis one has to consider using multiple univariate analyses (Huberty \& Morris, 1989; Carlson, 2017). There are four situations in which such approach is appropriate (Huberty \& Morris, 1989). One is when outcome variables are conceptually independent, second is when research conducted is exploratory in nature, third is when some or all of the outcome variables under current study have been previously studied in univariate contexts and fourth is when some evidence is needed to show that two groups of units are equivalent with respect to a number of descriptors (Huberty \& Morris, 1989). In the presented dataset all four of these requirements are met. The independent variables are conceptually different (organizational variables, variables of economic success and variables of IT use), the research is exploratory in nature, it attempts to show that two groups of units are equivalent with respect to a number of descriptors that should differ according to the established theory and independent variables included in the dataset were previously almost exclusively studied in univariate contexts. For these reasons it is sensible to proceed by using multiple univariate analyses of the dataset. From the univariate tests that analyze one scale variable and one categorical variable Student's independent sample t-tests is the most widely used by the scientific community (Huberty \& Morris, 1989; Sharma, 1996) and thus was selected as the statistical method of choice for this dataset. Because Student's t-tests analyze only the significance of the difference between the two tested groups' means and not the magnitude of the difference, we additionally calculate the effect size measure Cohen's delta for every t-test in order to address any 
potential "probability pyramiding problems" with Type I error (Huberty \& Morris, 1989). Thus we can state with a high degree of confidence that the selected statistical method will not influence the results. The decision to choose Cohen's delta as the analyzed effect size measure was based on the fact that from all effect size measures it is the one most commonly calculated and cited (Brand et al., 2010).

\subsection{Survey execution}

As the vast majority of other IT deployment studies in the literature (Bresnahan et al., 2002; Brynjolfsson et al., 2002; Mittal \& Nault, 2009; Hsu et al., 2015) this study was also focused on the biggest non-financial enterprises in the country. The studied population was the top thousand enterprises in Slovenia, based on the creation of value added in a year. These enterprises created $40 \%$ of total added value in the country in 2003 and employed $31 \%$ (285.357) of the workforce. However even between them there were 38 enterprises that had fewer than 25 employees. These enterprises were removed from the studied population. The reason behind such decision lies in the probability that these enterprises significantly differ from their bigger counterparts in organizational and other characteristics. 48 other enterprises were additionally removed because they exhibited larger fluctuations in earnings and employment then $+/-50 \%$. Such major changes in all likelihood represent outliers and can't be considered results of a normal business year. From the IT departments of the remaining 914 enterprises that thus composed the studied population 94 appropriately completed surveys were received. The survey of top 1000 enterprises in Slovenia is a reoccurring survey that was first implemented in 2005 and last performed in 2016 .

Based on personal and by phone communication with the IT managers involved in study it was found that the relatively low $10.28 \%$ response rate was mainly caused by the lack of time and/or knowledge needed to fill out the questionnaire. Tests of non-response bias were conducted to determine if the 94 "surveyed" enterprises adequately represent the studied population and can thus be thought of as a random sample from the studied population. These tests showed that there was no significant difference between the values known for the entire population and for the sample (number of employees, added value per enterprise, added value per employee, growth of added value) as long as the variable's sample relative standard deviation was smaller than $110 \%$. Since the sample relative standard deviations of variables with unknown population data (organizational characteristics, IT use, and relative economic success of enterprises) where lower than $65 \%$, it is reasonable to assume that non-response bias doesn't statistically significantly affect the variables relevant for this paper. Further tests also showed that the skewness and kurtosis for the studied variables did not exceed the ranges that would greatly violate the assumptions about the normal distribution of the variables, which would make parametric testing problematic (Sharma, 1996; Ozgur \& Strasser, 2004, Barret et al., 2005). Thus it can be stated that the sample in all likelihood adequately represents the population and can thus be used to conduct parametric testing for the studied variables. 


\section{Results}

Following the developed approach presented in Figure 1 we start the comparison between the groups of enterprises that predominantly invest into local and international enterprise software products by comparing their organizational characteristics. Table 2 presents the comparison of the cultural characteristics of the two groups of enterprises. Table 3 presents the comparison of strategic characteristics and Table 4 the comparison of structural characteristics.

Table 2. The comparison of cultural characteristics from Table 1 between the enterprises that predominantly invest in international enterprise software products and those that predominantly invest in local enterprise software products

\begin{tabular}{|c|c|c|c|c|c|c|c|c|}
\hline \multicolumn{5}{|c|}{$\begin{array}{l}\text { Basic statistics for the international and local } \\
\text { enterprise software product group of enterprises: }\end{array}$} & \multicolumn{4}{|c|}{$\begin{array}{l}\text { Independent Student's t-test and Cohen d } \\
\text { effect size between groups: }\end{array}$} \\
\hline \multicolumn{2}{|c|}{$\begin{array}{c}\text { Local group }=1, \\
\text { International group }=2\end{array}$} & \multirow{2}{*}{$\begin{array}{l}\mathrm{N} \\
25\end{array}$} & \multirow{2}{*}{$\begin{array}{c}\text { Mean } \\
3.36\end{array}$} & \multirow{2}{*}{\begin{tabular}{|c}
$\begin{array}{c}\text { Std. } \\
\text { Deviation }\end{array}$ \\
0.91
\end{tabular}} & \multirow{2}{*}{$\begin{array}{c}\mathrm{F} \\
0.00\end{array}$} & \multirow{2}{*}{$\begin{array}{l}\text { Sig. } \\
0.97\end{array}$} & \multicolumn{2}{|c|}{ Sig. (2-tailed)/Cohen } \\
\hline $\begin{array}{l}\text { Improved } \\
\text { support of the } \\
\text { emplovees by }\end{array}$ & 1 & & & & & & $\begin{array}{l}\text { Equal varian- } \\
\text { ces assumed }\end{array}$ & 0.05 \\
\hline superiors & 2 & 24 & 3.88 & 0.90 & & & Cohen $\mathrm{d}$ & 0.58 \\
\hline \multirow{2}{*}{$\begin{array}{l}\text { Improved } \\
\text { commitment } \\
\text { of the } \\
\text { employees }\end{array}$} & 1 & 25 & 3.48 & 0.71 & 3.27 & 0.08 & $\begin{array}{l}\text { Equal varian- } \\
\text { ces assumed }\end{array}$ & 0.93 \\
\hline & 2 & 24 & 3.50 & 0.98 & & & Cohen d & 0.02 \\
\hline \multirow{2}{*}{$\begin{array}{l}\text { Improved } \\
\text { innovativeness }\end{array}$} & 1 & 25 & 3.72 & 1.10 & 2.99 & 0.09 & $\begin{array}{l}\text { Equal varian- } \\
\text { ces assumed }\end{array}$ & 0.33 \\
\hline & 2 & 24 & 4.00 & 0.88 & & & Cohen d & 0.29 \\
\hline \multirow[t]{2}{*}{$\begin{array}{l}\text { Improved } \\
\text { control }\end{array}$} & 1 & 25 & 3.00 & 0.82 & 0.03 & 0.87 & $\begin{array}{l}\text { Equal } \\
\text { variances } \\
\text { assumed }\end{array}$ & 0.13 \\
\hline & 2 & 24 & 3.33 & 0.70 & & & & 0.45 \\
\hline \multirow{2}{*}{$\begin{array}{l}\text { Improved } \\
\text { continuous } \\
\text { learning }\end{array}$} & 1 & 25 & 2.92 & 0.76 & 1.40 & 0.24 & $\begin{array}{l}\text { Equal varian- } \\
\text { ces not } \\
\text { assumed }\end{array}$ & 0.00 \\
\hline & 2 & 24 & 3.63 & 0.82 & & & Cohen $\mathrm{d}$ & 0.91 \\
\hline
\end{tabular}

The comparison of cultural characteristics between the enterprises that predominantly invest in international pre-configured software products and those that predominantly invest in local software products shows only one statistically significant difference with a large Cohen's delta effect size. Thus the only cultural characteristic that is statistically significantly and importantly better deployed in the enterprises that predominantly invest in international software products is improved continuous learning. Another cultural characteristic that was almost statistically significantly better deployed by the international enterprise software group was the characteristic of improved support of the employees by the superiors (P-value $=0.052$ ) with a moderate Cohen's delta effect size. Other cultural characteristics didn't show 
any relevant differences between the two studied groups of enterprises. Based on the Table 1 presented in section 2 and the established positive effects all five characteristics have on enterprise software products in the literature, we can state that international vendors and their local consulting partners were not very successful in improving key cultural risk factors that strongly impact the success of investments in international enterprise software products. The fact that organizational changes in this dimension require most effort and time of any organizational changes (Adler \& Shenhar, 1990) can explain why such change is hard to achieve. However, one has also to start questioning the legitimacy of ERP packages as reflecting best practices that taken for granted (Liang \& Xue, 2004). Another possible explanation is that in Slovenia enterprises often implement continuous learning as a key requirement of ISO standards. It would be reasonable for enterprise that decided to adopt the international ISO standards to invest into international pre-configured software products that support such standard and have the built-in know-how of how to deploy such standard. No matter which explanation one favors the fact remains that a successful deployment of international enterprise software product should require a change of all five cultural characteristics to be in line with the US empirical findings on required complementary cultural characteristic for productive use of enterprise software.

Table 3. The comparison of strategic characteristics between the enterprises that predominantly invest in pre-configured software products and those that predominantly invest in custom software products

\begin{tabular}{|l|c|c|c|c|c|c|l|c|}
\hline \multicolumn{3}{|c|}{$\begin{array}{c}\text { Basic statistics for the international and local enterprise } \\
\text { software product group of enterprises: }\end{array}$} & \multicolumn{3}{|c|}{$\begin{array}{r}\text { Independent Student's t-test and Cohen d } \\
\text { effect size between groups: }\end{array}$} \\
\hline $\begin{array}{l}\text { Local group = 1, } \\
\text { International group = }\end{array}$ & $\mathrm{N}$ & Mean & $\begin{array}{c}\text { Std. } \\
\text { Deviation }\end{array}$ & $\mathrm{F}$ & Sig. & \multicolumn{2}{|c|}{ Sig. (2-tailed)/Cohen d } \\
\hline $\begin{array}{l}\text { Increased } \\
\text { sophistication } \\
\text { of strategic } \\
\text { planning }\end{array}$ & 1 & 25 & 3.44 & 1.08 & 3.36 & 0.07 & $\begin{array}{l}\text { Equal variances } \\
\text { assumed }\end{array}$ & 0.01 \\
\cline { 2 - 9 } & 2 & 24 & 4.13 & 0.74 & & & Cohen d & 0.75 \\
\hline $\begin{array}{l}\text { Improving cost } \\
\text { leadership }\end{array}$ & 1 & 25 & 3.64 & 0.99 & 3.05 & 0.09 & $\begin{array}{l}\text { Equal variances } \\
\text { assumed }\end{array}$ & 0.04 \\
\cline { 2 - 10 } & 2 & 24 & 4.17 & 0.70 & & & Cohen d & 0.62 \\
\hline $\begin{array}{l}\text { Improving } \\
\text { product } \\
\text { differentiation }\end{array}$ & 2 & 24 & 4.33 & 0.56 & & & $\begin{array}{l}\text { Equal variances } \\
\text { assumed }\end{array}$ & 0.06 \\
\hline $\begin{array}{l}\text { Increasing the } \\
\text { use of inter- } \\
\text { organisational } \\
\text { synergies }\end{array}$ & 1 & 25 & 3.40 & 0.96 & 2.56 & 0.12 & $\begin{array}{l}\text { Equal variances } \\
\text { assumed }\end{array}$ & 0.05 \\
\cline { 2 - 10 } & 2 & 24 & 3.92 & 0.72 & & & Cohen d & 0.58 \\
\hline $\begin{array}{l}\text { Increasing } \\
\text { bargaining } \\
\text { power in the } \\
\text { supply chain }\end{array}$ & 1 & 25 & 3.68 & 0.99 & 1.75 & 0.19 & $\begin{array}{l}\text { Equal variances } \\
\text { assumed }\end{array}$ & 0.04 \\
\cline { 2 - 10 } & 2 & 24 & 4.17 & 0.70 & & & Cohen d & 0.62 \\
\hline
\end{tabular}

The comparison between the strategic characteristics of the two studied groups of enterprises presented in Table 3 exposes much greater differences then was the case for the cultural 
characteristics. All five characteristics exhibit a moderate size Cohen's delta. Sophistication of strategic planning, cost leadership and bargaining power in the supply chain is additionally statistically significantly different between the two groups. Thus we can conclude that the enterprises who predominantly invest in international enterprise software products have a higher quality processes of strategic planning, bargaining and cost leadership than the enterprises that predominantly invest in local software products. Based on results presented in Table 3 we can state that the management of strategic risk factors i.e. improvement of organizational characteristics that are required complements for productive use of international enterprise software products (Table 1) is significantly more successful than for the cultural risk factors. The enterprises that open themselves to foreign best practices in this organizational dimension exhibit significant and relevant improvements of key strategic characteristics over

Table 4. The comparison of strategic characteristics between the enterprises that predominantly invest in pre-configured software products and those that predominantly invest in custom software products

\begin{tabular}{|c|c|c|c|c|c|c|c|c|}
\hline \multicolumn{5}{|c|}{$\begin{array}{l}\text { Basic statistics for the international and local } \\
\text { enterprise software product group of enterprises: }\end{array}$} & \multicolumn{4}{|c|}{$\begin{array}{l}\text { Independent Student's t-test and Cohen d } \\
\text { effect size between groups: }\end{array}$} \\
\hline \multicolumn{2}{|c|}{$\begin{array}{c}\text { Local group }=1, \\
\text { International group }=2\end{array}$} & \multirow{2}{*}{$\begin{array}{l}\mathrm{N} \\
25\end{array}$} & \multirow{2}{*}{$\begin{array}{r}\text { Mean } \\
3.16\end{array}$} & \multirow{2}{*}{$\begin{array}{c}\begin{array}{c}\text { Std. } \\
\text { Deviation }\end{array} \\
0.90\end{array}$} & \multirow{2}{*}{$\begin{array}{c}\mathrm{F} \\
0.08\end{array}$} & \multirow{2}{*}{$\begin{array}{l}\text { Sig. } \\
0.78\end{array}$} & \multicolumn{2}{|c|}{ Sig. (2-tailed)/Cohen d } \\
\hline \multirow{2}{*}{$\begin{array}{l}\text { Decreasing } \\
\text { Centralization }\end{array}$} & 1 & & & & & & $\begin{array}{l}\text { Equal variances } \\
\text { assumed }\end{array}$ & 0.51 \\
\hline & 2 & 24 & 3.33 & 0.92 & & & Cohen $\mathrm{d}$ & 0.20 \\
\hline \multirow{2}{*}{$\begin{array}{l}\text { Increasing } \\
\text { group/team } \\
\text { based method } \\
\text { of work }\end{array}$} & 1 & 25 & 2.92 & 0.86 & 1.08 & 0.30 & $\begin{array}{l}\text { Equal variances } \\
\text { assumed }\end{array}$ & 0.04 \\
\hline & 2 & 24 & 3.46 & 0.88 & & & Cohen $\mathrm{d}$ & 0.63 \\
\hline \multirow{2}{*}{$\begin{array}{l}\text { Decreasing } \\
\text { Formalization }\end{array}$} & 1 & 25 & 2.80 & 0.96 & 0.43 & 0.52 & $\begin{array}{l}\text { Equal variances } \\
\text { assumed }\end{array}$ & 0.17 \\
\hline & 2 & 24 & 3.17 & 0.87 & & & Cohen d & 0.41 \\
\hline \multirow{2}{*}{$\begin{array}{l}\text { Decreasing } \\
\text { vertical } \\
\text { differentiation }\end{array}$} & 1 & 25 & 3.28 & 0.84 & 0.75 & 0.39 & $\begin{array}{l}\text { Equal variances } \\
\text { assumed }\end{array}$ & 0.54 \\
\hline & 2 & 24 & 3.42 & 0.72 & & & Cohen $\mathrm{d}$ & 0.18 \\
\hline \multirow{2}{*}{$\begin{array}{l}\text { Decreasing } \\
\text { Specialization }\end{array}$} & 1 & 25 & 3.24 & 0.88 & 0.67 & 0.42 & $\begin{array}{l}\text { Equal variances } \\
\text { assumed }\end{array}$ & 0.06 \\
\hline & 2 & 24 & 3.75 & 0.99 & & & Cohen d & 0.56 \\
\hline \multirow{2}{*}{$\begin{array}{l}\text { Increasing } \\
\text { professio- } \\
\text { nalization }\end{array}$} & 1 & 25 & 2.84 & 0.94 & 0.02 & 0.90 & $\begin{array}{l}\text { Equal variances } \\
\text { assumed }\end{array}$ & 0.02 \\
\hline & 2 & 24 & 3.46 & 0.88 & & & Cohen d & 0.69 \\
\hline \multirow{2}{*}{$\begin{array}{l}\text { Increasing goal } \\
\text { oriented } \\
\text { remuneration } \\
\text { system }\end{array}$} & 1 & 25 & 2.76 & 1.16 & 2.41 & 0.13 & $\begin{array}{l}\text { Equal variances } \\
\text { assumed }\end{array}$ & 0.09 \\
\hline & 2 & 24 & 3.29 & 0.95 & & & Cohen d & 0.51 \\
\hline \multirow{2}{*}{$\begin{array}{l}\text { Increasing } \\
\text { communication } \\
\text { with the } \\
\text { environment }\end{array}$} & 1 & 25 & 2.96 & 0.93 & 1.26 & 0.27 & $\begin{array}{l}\text { Equal variances } \\
\text { assumed }\end{array}$ & 0.04 \\
\hline & 2 & 24 & 3.54 & 1.02 & & & Cohen d & 0.61 \\
\hline
\end{tabular}


the enterprises that limit themselves to redeploying internal best practices, when investing in local enterprise software products. Because of the lack of strategic alignment (Centobelli et al., 2018) in enterprises in Slovenia that invest in local enterprise software products, we can also conclude that there is a general lack of business sophistication which negatively affects their innovation capacity (Kirikkaleli \& Ozun, 2019).

The comparison of structural characteristics of the two studied groups of enterprises presented in Table 4 reveals 5 characteristics with medium size Cohen's delta. Among these only the differences between groups for team based method of work, professionalization and communication with the environment are statistically significant, while the differences between groups for decreased specialization and increased goal oriented remuneration are not. Even more surprising is the fact that there is no significant and relevant difference between the international and local enterprise software investment group when it comes to establishing a flat hierarchical structure. The flattening of the hierarchical structure through decreased centralization, decreased formalization and decreased vertical differentiation is considered to be a key structural risk factor that needs to be addressed for a successful deployment of enterprise software products. It serves as a main indicator that an enterprise has transformed its organization into a process-oriented organic organization that brings managers closer to the customers and enables a more efficient and effective execution of work tasks in the IT age (Kim \& Ramkaran, 2003). The lack of such process-oriented transformation leads to the conclusion that at its core even the group of enterprises that predominantly invest in international enterprise software products continue to function as classic Smith and Taylor type organizations with questionable long term sustainability (Chofreh et al., 2018). Thus we cannot speak of a successful management of structural risk factors that positively influence the success of investments in international enterprise software products.

Table 5. The comparison of indicators of IT use and of economic performance between the enterprises that predominantly invest in international and those that predominantly invest in local software products

\begin{tabular}{|l|c|c|c|c|c|c|l|c|}
\hline \multicolumn{3}{|c|}{$\begin{array}{c}\text { Basic statistics for the international and local enterprise } \\
\text { software product group of enterprises: }\end{array}$} & \multicolumn{3}{c|}{$\begin{array}{c}\text { Independent Student's t-test and } \\
\text { Cohen d effect size between groups: }\end{array}$} \\
\hline $\begin{array}{c}\text { Local group = 1, } \\
\text { International group }=2\end{array}$ & $\mathrm{~N}$ & Mean & $\begin{array}{c}\text { Std. } \\
\text { Deviation }\end{array}$ & $\mathrm{F}$ & Sig. & Sig. (2-tailed)/Cohen d \\
\hline \multirow{2}{*}{$\begin{array}{l}\text { Added Value per } \\
\text { Employee 2003 }\end{array}$} & 1 & 25 & $33,550 €$ & $25,230 €$ & 0.525 & 0.472 & $\begin{array}{l}\text { Equal variances } \\
\text { assumed }\end{array}$ & 0.606 \\
\cline { 2 - 9 } & 2 & 24 & $37,840 €$ & $32,319 €$ & & & Cohen d & 0.15 \\
\hline \multirow{2}{*}{$\begin{array}{l}\text { Added Value per } \\
\text { Employee 2004 }\end{array}$} & 1 & 25 & $35,061 €$ & $24,381 €$ & 1.142 & 0.291 & $\begin{array}{l}\text { Equal variances } \\
\text { assumed }\end{array}$ & 0.467 \\
\cline { 2 - 9 } & 2 & 24 & $41,285 €$ & $34,377 €$ & & & Cohen d & 0.21 \\
\hline $\begin{array}{l}\text { Growth of Added } \\
\text { value in 2004 }\end{array}$ & 1 & 25 & $109.14 \%$ & $17.37 \%$ & 2.073 & 0.157 & $\begin{array}{l}\text { Equal variances } \\
\text { assumed }\end{array}$ & 0.647 \\
\cline { 2 - 9 } & 2 & 24 & $107.03 \%$ & $14.46 \%$ & & & Cohen d & 0.13 \\
\hline $\begin{array}{l}\text { Growth of Added } \\
\text { value per employee } \\
\text { in 2004 }\end{array}$ & 1 & 25 & $106.76 \%$ & $16.94 \%$ & 0.486 & 0.489 & $\begin{array}{l}\text { Equal variances } \\
\text { assumed }\end{array}$ & 0.388 \\
\cline { 2 - 9 } & 2 & 24 & $110.92 \%$ & $16.44 \%$ & & & Cohen d & 0.25 \\
\hline
\end{tabular}


End of Table 5

\begin{tabular}{|c|c|c|c|c|c|c|c|c|}
\hline \multicolumn{5}{|c|}{$\begin{array}{l}\text { Basic statistics for the international and local enterprise } \\
\text { software product group of enterprises: }\end{array}$} & \multicolumn{4}{|c|}{$\begin{array}{l}\text { Independent Student's t-test and } \\
\text { Cohen d effect size between groups: }\end{array}$} \\
\hline \multicolumn{2}{|c|}{$\begin{array}{l}\text { Local group }=1, \\
\text { International group }=2\end{array}$} & \multirow{2}{*}{$\begin{array}{l}\mathrm{N} \\
25\end{array}$} & \multirow{2}{*}{$\begin{array}{c}\text { Mean } \\
3.44\end{array}$} & \multirow{2}{*}{$\begin{array}{c}\begin{array}{c}\text { Std. } \\
\text { Deviation }\end{array} \\
0.506\end{array}$} & \multirow{2}{*}{$\begin{array}{c}\mathrm{F} \\
5.326\end{array}$} & \multirow{2}{*}{$\begin{array}{c}\text { Sig. } \\
0.026\end{array}$} & \multicolumn{2}{|c|}{ Sig. (2-tailed)/Cohen d } \\
\hline $\begin{array}{l}\text { Growth of Added } \\
\text { value in } 2004\end{array}$ & 1 & & & & & & $\begin{array}{l}\text { Equal variances } \\
\text { not assumed }\end{array}$ & 0.981 \\
\hline $\begin{array}{l}\text { relative to the } \\
\text { industry }\end{array}$ & 2 & 24 & 3.43 & 0.895 & & & Cohen d & 0.01 \\
\hline \multirow{2}{*}{$\begin{array}{l}\text { Growth of Added } \\
\text { Value between } \\
\text { 2000-2004 relative } \\
\text { to the industry }\end{array}$} & 1 & 25 & 3.68 & 0.802 & 0.137 & 0.713 & $\begin{array}{l}\text { Equal variances } \\
\text { assumed }\end{array}$ & 0.401 \\
\hline & 2 & 24 & 3.47 & 0.845 & & & Cohen d & 0.25 \\
\hline \multirow{2}{*}{$\begin{array}{l}\text { Maximum } \\
\text { potential IT use }\end{array}$} & 1 & 25 & $61.76 \%$ & $18.81 \%$ & 0.053 & 0.819 & $\begin{array}{l}\text { Equal variances } \\
\text { assumed }\end{array}$ & 0.664 \\
\hline & 2 & 24 & $64.17 \%$ & $19.68 \%$ & & & Cohen $\mathrm{d}$ & 0.13 \\
\hline \multirow[t]{2}{*}{ Actual IT use } & 1 & 25 & $49.16 \%$ & $17.85 \%$ & 0.003 & 0.954 & $\begin{array}{l}\text { Equal variances } \\
\text { assumed }\end{array}$ & 0.509 \\
\hline & 2 & 24 & $52.76 \%$ & $19.97 \%$ & & & Cohen $\mathrm{d}$ & 0.19 \\
\hline \multirow[t]{2}{*}{ IT utilization rate } & 1 & 25 & $79.39 \%$ & $11.45 \%$ & 2.009 & 0.163 & $\begin{array}{l}\text { Equal variances } \\
\text { assumed }\end{array}$ & 0.604 \\
\hline & 2 & 24 & $81.49 \%$ & $16.49 \%$ & & & Cohen $\mathrm{d}$ & 0.15 \\
\hline
\end{tabular}

Table 5 confirms such assessment and furthermore lets us state that the current risk management of organizational characteristics that positively impact the success of investment in international enterprise software products is not sufficient to produce relevant and significant differences in indicators of IT use and economic success between the two studied groups of enterprises. International software vendors and their local business partners marketing claims that international enterprise software products will enable enterprises to achieve a competitive edge, spur growth of added value and significantly raise the productivity of their employees (IDC, 2007) thus the studied data doesn't support. In fact, the decision of enterprises to predominantly invest in international vs. local enterprise software products does not appear to lead to any relevant and significant differences in IT use or economic success of enterprises. Based on the empirical results from other countries to achieve such gains the current quality of the deployment of international enterprise software products would need to be significantly improved by raising the quality and quantity of ICT professionals in local business partners of international enterprise software vendors, as well as in the the top 1000 enterprises themselves (Taştan \& Gönel, 2020).

\section{Discussion}

The results of the empirical study enable us to answer all four research questions that were formulated at the beginning of this paper. 
In accordance with the international literature we identified 18 organizational characteristics in 3 organizational dimensions (culture, strategy and structure) that are required complements for successful investments in international enterprise software products (RQ1). These characteristics are presented in Table 1 while Tables 2, 3 and 4 empirically compare the average value and distribution of these characteristics for the two studied groups of enterprises (groups of enterprises that predominantly invest in international vs. local international enterprise software products). While the empirical comparison found two (out of five) relevant and significant differences in the cultural dimension, three (out of five) relevant and significant differences in the strategic dimension and three (out of eight) relevant and significant differences in structural dimension the remaining ten organizational characteristics didn't show relevant and significant differences between the studied groups. Thus we can conclude that investments in international enterprise software products were accompanied by only $44 \%$ ( 8 out of 18 ) of those organizational characteristics that the literature finds as required for/complementary with successful investments in international enterprise software products (RQ2).

According to the results presented in Table 5 we can't reject the hypothesis that there are no relevant and statistically significant differences in efficiency of IT use or economic performance between the groups of enterprises that predominantly invest in pre-configured software products and those that predominantly invest in local software products (RQ3). However such results cannot be definitely interpreted as a failure of international enterprise software products to generate added value in enterprises outside of their country/culture (USA/Anglo-Saxon) of origin (Hofstede, 1980, 2003), since the quality of the deployment of required complementary organizational characteristics by the local IT consultants did not achieve the standards expected in the reviewed international literature. Such unsuccessful deployment of complementary organizational characteristics can probably be explained with the way enterprises in Slovenia select local consultants that should help them implement the international enterprise software products. This is generally not a meritocratic selection process but is a process based on personal connections and political influences (Podobnik, 2004; Slovenian Press Agency, 2011). As a transition economy with significant corruption problems that is attempting to adopt the German coordinated market economy the market of local IT consultants is on average not capable of producing successful deployments of complementary organizational characteristics for successful use of enterprise software products.

Likewise, we can conclude that investments in local enterprise software products that should exhibit a better fit with the existing organizational characteristics of enterprises in Slovenia do not perform any better or worse than investments in international software products. Nevertheless such findings go against the widely established perception that international enterprise software products are universally best at delivering competitive advantage, spurring added value growth and significantly raising the productivity of employees, even though such view is strongly promoted by the large majority of the top 50 IT vendors in Slovenia (Slovenian Chamber of Commerce, 2004; IDC, 2007). Accordingly local IT vendors are increasingly switching from selling locally developed enterprise software products to selling software from the big international vendors such as SAP, IBM, ORACLE and/or Microsoft (Slovenian Chamber of Commerce, 2004; IDC, 2007). Such trends aren't surprising if one 
takes into account the natural ability of large international vendors to define perceptions in small markets.

The analysis of the results of the empirical study showed that the proposed approach was able to identify the quality of deployment of complementary organizational characteristics required for successful investments in international enterprise software products. Thus any enterprise can use our model and our scales to evaluate the quality of these organizational characteristics in their enterprise and compare them with means and standard deviations for the two studied group of enterprises in our paper. If the quality values of their organizational characteristics are not statistically significantly higher than the means of values of the group that predominantly invests in local enterprise software products and they still decide to invest in international software products, they are taking on significant risks that these investments will fail. Our model also enables them to see which of the 18 complementary organizational characteristics are problematic, which can help them direct the effort in improving their quality. Additionally, our model enables them to evaluate how successful the deployment of international enterprise software product by local consultants was, since a before-after analysis of the organizational characteristics in the model provides a clear assessment of how much each characteristic was improved. By identifying if and where the lack of improvement is present, the proposed model again enables managers to develop specific actions to address the individual organizational issues. In this way the proposed approach provides managers with non-trivial information that helps them evaluate the risks of investments in international enterprise software products and helps them improve the quality of the deployment of the required organizational characteristics for successful investments in international enterprise software products (RQ4). Even if we assume that the results (means and standard deviations) in themselves are not generalizable to different countries, the proposed approach would remain useful for enterprises since the model retains its ability to identify the quality of the deployment of complementary organizational characteristics required for successful investments in international enterprise software products. Enterprises would thus still be able to better evaluate the risk of such investments by analyzing their own differences between low and high values of complementary organizational characteristics to identify and monitor the low value organizational characteristics that pose significant risks to successful investments.

\section{Conclusions}

The paper presents and empirically tests a novel approach for monitoring and evaluating the success of the investments in international enterprise software products (ERP, SCM, $\mathrm{CRM}, \ldots$... The approach enables the enterprises to better understand, evaluate and manage the deployment of international enterprise software products, thus hopefully increasing the success of such investments.

In order to develop a viable approach for monitoring and evaluating the success of the deployment of pre-configured best practices the paper had to successfully respond to four main research questions. To respond to the first research question (RQ1) a comprehensive review of related work was conducted in order to form a list of those organizational characteristics that are complementary with/required for a successful investments in international enter- 
prise software products. This list of organizational characteristics formed the basis on which the proposed approach was built. To respond to the remaining three research questions, the approach was tested on a representative sample of 1000 biggest enterprises in Slovenia, where we compared the organizational characteristics and economic success of the group of enterprises that predominantly invest in international software products and the group of enterprises that predominantly invest in local enterprise software products. Such comparison allowed us to answer the second research question (RQ2) and state that on average there are significant and relevant differences between the two groups in $44 \%$ of the examined organizational characteristics. The fact that there are not larger organizational differences between the two groups is in all likelihood also the main reason why the deployment of international enterprise software products doesn't bring measurable improvements to productivity growth compared to investments in local software products (RQ3). Because the proposed approach evaluates the quality of deployment of complementary/required organizational characteristic for successful investments in international enterprise software products any enterprise can use the model to analyze their own organizational risks when conducting such investments. Additionally, the proposed approach can be used for specific before-after analysis to ascertain if and were the unsolved organizational issues for successful deployment of international enterprise software products are. We hope that the proposed approach will provide valuable information to managers and increase the success of deployment of international enterprise software products all over the globe by improving the assessment of compatibility between the organizational characteristics of individual enterprises and international enterprise software products (RQ4).

Even though the empirical results support the viability of the proposed approach certain limitations still need to be addressed. Empirical tests of the proposed approach are for now limited to Slovenia. For this reason, it would be of benefit to conduct similar quantitative tests or qualitative studies in other countries. Of special interest would be to conduct such research were selection of local consultants that deploy the pre-configured software products is not based so much on personal and political connections but meritocracy.

Further work should thus concentrate on examining the usefulness of the proposed approach in different national environments. We believe that the proposed approach and the empirical results presented in this paper are a good foundation for such further research.

\section{Author contributions}

Tomaž Hovelja and Rok Rupnik were responsible for the study conducting in Slovenia, obtained results analysis, conducting discussion and conclusions. Olegas Vasilecas has developed a method schema and wrote the first draft of the article. Diana Kalibatiene was responsible for data interpretation, related works analysis. She has refined the text and prepared the paper for the submission to the journal.

\section{Disclosure statement}

Authors have no any competing financial, professional, or personal interests from other parties. 


\section{References}

Adler, P., \& Shenhar, A. (1990). Adapting your technological base: The organizational challenge. Sloan Management Review, 32(1), 25-37.

Aloini, D., Dulmin, R., \& Mininno, V. (2007). Risk management in ERP project introduction: Review of the literature. Information and Management, 44(6), 547-567.

https://doi.org/10.1016/j.im.2007.05.004

Aloini, D., Dulmin, R., \& Mininno, V. (2012). Risk assessment in ERP projects. Information Systems, 37(3), 183-199. https://doi.org/10.1016/j.is.2011.10.001

Baker, K. A. (2002). Organizational culture. Office of Science.

Bakos, J. Y., \& Treacy, M. E. (1986). Information technology and corporate strategy: A research perspective. Management Information Systems Quarterly, 10(2), 107-119. https://doi.org/10.2307/249029

Barfield, J., Poulsen, J., \& French, A. (2004). Discriminant Function Analysis (DA). Retrieved October 2019, from http://userwww.sfsu.edu/efc/classes/biol710/discrim/discriminant.htm

Barrett, K., Leech, N., \& Morgan, G. (2005). SPSS for intermediate statistics: Use and interpretation. Lawrence Erlbaum Associates.

Bartel, A., Ichniowski, C., \& Shaw, K. (2007). How does information technology affect productivity? Plant-level comparisons of product innovation, process improvement and worker skills. The Quarterly Journal of Economics, 122(4), 1721-1758. https://doi.org/10.1162/qjec.2007.122.4.1721

Basu, S., \& Fernald, J. (2007). Information and communications technology as a general-purpose technology: Evidence from US industry data. German Economic Review, 8(5), 146-173. https://doi.org/10.1111/j.1468-0475.2007.00402.x

Batenburg, R., Helms, R. W., \& Versendaal, J. (2006). PLM roadmap: Stepwise PLM implementation based on the concepts of maturity and alignment. International Journal of Product Lifecycle Management, 1(4), 333-351. https://doi.org/10.1504/IJPLM.2006.011053

Beath, C., Silver, M., \& Markus, L. (1995). The information technology interaction model: A foundation for the MBA core course. Management Information Systems Quarterly, 19(3), 361-390. https://doi.org/10.2307/249600

Bergeron, F., Uqtr, L. R., \& Rivard, S. (2002). Strategic alignment and business performance: Operationalizing and testing a covariation model (Workbook nb. 02-01). HEC Montreal.

Tagliavini, M., Pigni, F., Ravarini, A., \& Buonanno, G. (2001, October). Empirically testing the impact of ICT on business performance within SMEs. In $11^{\text {th }}$ Annual Business IT Management Conference: Constructing IS Futures, Manchester.

Brand, A., Bradley, M., Best, L., \& Stoica, G. (2010). Multiple trials may yield exaggerated effect size estimates. The Journal of General Psychology, 138(1), 1-11. https://doi.org/10.1080/00221309.2010.520360

Bresnahan, T. F. (2001). The mechanisms of information technology's contribution to economic growth. Stanford University. Retrieved August 3, 2019, from https://web.stanford.edu/ tbres/research/ mechanisms_of_it_contribution.pdf

Bresnahan, T. F. (2003). The mechanisms of information technology's contribution to economic growth. In J.-P. Touffut (Ed.), Institutions, innovation and growth. Selected economic papers (Chapter 5). Edward Elgar.

Bresnahan, T., Brynjolfsson, E., \& Hitt, L. (2002). Information technology, workplace organization, and the demand for skilled labor: Firm-level evidence. Quarterly Journal of Economics, 117(1), 339-376. https://doi.org/10.1162/003355302753399526

Brown, S. P., \& Leigh, T. W. (1996). A new look at psychological climate and its relationship to job involvement, effort, and performance. Journal of Applied Psychology, 81(4), 358.

https://doi.org/10.1037/0021-9010.81.4.358 
Brynjolfsson, E., Hitt, L., \& Yang, S. (2002). Intangible assets: How the interaction of computers and organizational structure affects stock market valuations. Sloan School of Management, Cambridge. Retrieved October 15, 2002, from http://ebusiness.mit.edu/research/papers/138_Erik_Intangible_ Assets.pdf

Brzozowski, M., \& Birfer, I. (2017). Applications of MCDM methods in the ERP system selection process in enterprises. Handel Wewnetrzny, 3(368), 40-52.

Cameron, K. (2008). A process for changing organization culture. Handbook of Organization Development, 14(5), 2-18.

Carlson, D. (2017). Quantitative methods in archaeology using R. Cambridge University Press. https://doi.org/10.1017/9781139628730

Centobelli, P., Cerchione, R., \& Esposito, E. (2018). Aligning enterprise knowledge and knowledge management systems to improve efficiency and effectiveness performance: A three-dimensional Fuzzy-based decision support system. Expert Systems with Applications, 91, 107-126. https://doi.org/10.1016/j.eswa.2017.08.032

Chen, P. S., Yen, D. C., Lin, S. C., \& Chou, C. S. (2018). Toward an IT investment decision support model for global enterprises. Computer Standards \& Interfaces, 59, 130-140. https://doi.org/10.1016/j.csi.2018.04.001

Chofreh, A., Goni, F., \& Klemeš, J. (2018). Sustainable enterprise resource planning systems implementation: A framework development. Journal of Cleaner Production, 198, 1345-1354. https://doi.org/10.1016/j.jclepro.2018.07.096

Damanpour, F. (1991). Organizational innovation: A meta-analysis of effects of determinants and moderators. Academy of Management Journal, 34(3), 555-590. https://doi.org/10.5465/256406

Daveri, F. (2004). Delayed IT usage: Is it really the drag on Europe's productivity? CESifo Economic Studies, 50(3), 397-421. https://doi.org/10.1093/cesifo/50.3.397

Davidavičienė, V., Raudeliūnienè, J., Vengrienè, E., \& Jakubavičius, A. (2018). Consolidation of the activities of regulatory institutions while implementing e-government solutions. Journal of Business Economics and Management, 19(2), 307-322. https://doi.org/10.3846/jbem.2018.5534

de Santana, G. A., Mascarenhas e Silva, F., de Alencar e Silva, E. J., \& Domingos, L. A. (2018). Adoption of innovation processes in a period of crisis by the companies of Petrolina-PE. Navus-Revista De Gestao E Tecnologia, 8(4), 167-179. https://doi.org/10.22279/navus.2018.v8n4.p167-179.734

Dedrick, J., Kraemer, K. L., \& Shih, E. (2013). Information technology and productivity in developed and developing countries. Journal of Management Information Systems, 30(1), 97-122. https://doi.org/10.2753/MIS0742-1222300103

Delobbe, N., Haccoun, R. R., \& Vandenberghe, C. (2002). Measuring core dimensions of organizational culture: A review of research and development of a new instrument (Unpublished manuscript). Universite catholique de Louvain, Belgium. Retrieved May 15, 2002, from https://growthorientedsustainableentrepreneurship.files.wordpress.com/2016/07/oc-core-dimensions-of-organizationalculture.pdf

Denison, D. R. (1997). Corporate culture and organizational effectiveness. John Wiley \& Sons.

Dey, P. K., Clegg, B., \& Cheffi, W. (2013). Risk management in enterprise resource planning implementation: A new risk assessment framework. Production Planning \& Control, 24(1), 1-14. https://doi.org/10.1080/09537287.2011.597038

Dewett, T., \& Jones, G. R. (2001). The role of information technology in the organization: A review, model, and assessment. Journal of Management, 27(3), 313-346. https://doi.org/10.1177/014920630102700306

Ehie, C., \& Madsen, M. (2005). Identifying critical issues in enterprise resource planning (ERP) implementation. Computers in Industry, 56(6), 545-557. https://doi.org/10.1016/j.compind.2005.02.006 
Enea, M., \& Piazza, T. (2004). Project selection by constrained fuzzy AHP. Fuzzy Optimization and Decision Making, 3(1), 39-62. https://doi.org/10.1023/B:FODM.0000013071.63614.3d

Fichman, R. G. (2000). The diffusion and assimilation of information technology innovations. In R. Zmud (Ed.), Framing the domains of IT management: Projecting the future... through the past (pp. 105-128). Pinnaflex Educational Resources inc.

Fichman, R. G., \& Kemerer, C. F. (1997). The assimilation of software process innovations: An organizational learning perspective. Management Science, 43(10), 1345-1363. https://doi.org/10.1287/mnsc.43.10.1345

Fiedler, K. D., Grover, V., \& Teng, J. T. (1996). An empirically derived taxonomy of information technology structure and its relationship to organizational structure. Journal of Management Information Systems, 13(1), 9-34. https://doi.org/10.1080/07421222.1996.11518110

Garg, A. K., Joubert, R. J. O., \& Pellissier, R. (2002). Review of strategic alignment: Its meaning, measurement and impact on business performance. Southern African Business Review, 6(1), 38-44.

Garg, P., \& Agarwal, D. (2014). Critical success factors for ERP implementation in a Fortis hospital: An empirical investigation. Journal of Enterprise Information Management, 27(4), 402-423. https://doi.org/10.1108/JEIM-06-2012-0027

Gimenez, A., \& Suarez, R. (2004). Interactions between information technologies and the organization: A conceptual and empirical approach. Universidad Politécnica Madrid. Retrieved January 22, 2004, from http://www.ifsam.org/1998/DATA/1.PD

Gospodarska zbornica Slovenije [Slovenian Chamber of Commerce]. (2004). Analiza slovenskega sektorja IKT kot osnova za strategijo njegovega razvoja [Analysis of Slovenian ICT sector as the basis for its development strategy]. Gospodarska zbornica Slovenije, Ljubljana. Retrieved June 29, 2004, from http://www.gzs.si/publikacije/prikazl.asp?ids=2083

Goyettea, S., Cassivia, L., Courchesnea, M., \& Eliaa, E. (2014). Knowledge transfer mechanisms in an ERP post-implementation stage. Procedia Technology, 16, 430-439. https://doi.org/10.1016/j.protcy.2014.10.109

Gronwald, K.-D. (2017). Integrated business information systems: A holistic view of the linked business process chain ERP-SCM-CRM-BI-Big Data. Springer. https://doi.org/10.1007/978-3-662-55469-2

Grover, V., \& Goslar, M. D. (1993). The initiation, adoption, and implementation of telecommunications technologies in US organizations. Journal of Management Information Systems, 10(1), 141-164. https://doi.org/10.1080/07421222.1993.11517994

Gupta, Y. P., Karimi, J., \& Somers, T. M. (1997). Alignment of a firm's competitive strategy and information technology management sophistication: The missing link. IEEE Transactions on Engineering Management, 44(4), 399-413. https://doi.org/10.1109/17.649870

Gurbaxani, V., Kraemer, K., \& Melville, N. (2004). An integrative model of IT business value. Management Information Systems Quarterly, 28(2), 283-322. https://doi.org/10.2307/25148636

Haddara, M. (2014). ERP selection: The SMART way. Procedia Technology, 16, 394-403. https://doi.org/10.1016/j.protcy.2014.10.105

Hakim, A., \& Hakim, H. 2010. A practical model on controlling the ERP implementation risks. Information Systems, 35(2), 204-214. https://doi.org/10.1016/j.is.2009.06.002

Hammer, M., \& Champy, J. (1993). Reengineering the corporation: A manifesto for business revolution. Harper Collins Publishers.

Hawking, P. (2007). Implementing ERP systems globally: Challenges and lessons learned for Asian countries. Journal of Business Systems, Governance and Ethics, 2(1), 21-32. https://doi.org/10.15209/jbsge.v2i1.96

Hedman, J., \& Kalling, T. (2001). The business model: A means to understand the business context of information and communication technology (Institute of Economic Research Working Paper Series). https://aisel.aisnet.org/cgi/viewcontent.cgi?article=1064\&amp;context=ecis2002 
Heinzelmann, R. (2017). Accounting logics as a challenge for ERP system implementation: A field study of SAP. Journal of Accounting \& Organizational Change, 13(2), 162-187. https://doi.org/10.1108/JAOC-10-2015-0085

Henderson, J. C., \& Venkatraman, H. (1999). Strategic alignment: Leveraging information technology for transforming organizations. IBM Systems Journal, 38(2.3), 472-484. https://doi.org/10.1147/SJ.1999.5387096

Hofstede, G. (1980). Motivation, leadership and organization: Do American theories apply abroad? Organizational Dynamics, 10(1), 42-63. https://doi.org/10.1016/0090-2616(80)90013-3

Hofstede, G. (2003). Cultural constraints in management theories. Academy of Management Executive, 7(1), 1-94. https://doi.org/10.5465/ame.1993.9409142061

Hornos, M. J., \& Herrera-Viedma, E. (2018). Prioritization of the launch of ICT products and services through linguistic multi-criteria decision-making. Technological and Economic Development of Economy, 24(3), 1231-1257. https://doi.org/10.3846/tede.2018.1423

Hovelja, T. (2008). Organisational effects on information technology productivity in enterprises: The case of Slovenia. Economic and Business Review, 10(3), 243-261. https://doi.org/10.1111/j.1468-0475.2009.00468.x

Hovelja, T., Vasilecas, O., \& Rupnik, R. (2013). A model of influences of environmental stakeholders on strategic information systems planning success in an enterprise. Technological and Economic Development of Economy, 19(3), 465-488. https://doi.org/10.3846/20294913.2013.818591

Howcroft, D., \& Light, B. (2006). Reflections on issues of power in packaged software selection. Information Systems Journal, 16(3), 215-235. https://doi.org/10.1111/j.1365-2575.2006.00216.x

Hsu, P. F., Yen, H. R., \& Chung, J. C. (2015). Assessing ERP post-implementation success at the individual level: Revisiting the role of service quality. Information \& Management, 52(8), 925-942. https://doi.org/10.1016/j.im.2015.06.009

Huberty, C., \& Morris, J. (1989). Multivariate analysis versus multiple univariate analyses. Psychological Bulletin, 105(2), 302-308. https://doi.org/10.1037/0033-2909.105.2.302

IDC. (2007). Steady growth underlines big changes in Slovenian IT services market, says IDC. Prague: IDC. Retrieved 12 April, 2009 from http://www.idc-cema.com/? showproduct=31552

Inklaar, R., Mcgouckin, R., \& van Ark, B. (2003). ICT and productivity in Europe and the United States: Where do the differences come from? CESifo Economic Studies, 49(3), 295-318. https://doi.org/10.1093/cesifo/49.3.295

Jayawickrama, U., Liu, S., \& Hudson Smith, M. (2017). Knowledge prioritisation for ERP implementation success: Perspectives of clients and implementation partners in UK industries. Industrial Management \& Data Systems, 117(7), 1521-1546. https://doi.org/10.1108/IMDS-09-2016-0390

Junior, F. R., Osiro, L., \& Carpinetti, L. C. (2014). A comparison between Fuzzy AHP and Fuzzy TOPSIS methods to supplier selection. Applied Soft Computing, 21, 194-209. https://doi.org/10.1016/j.asoc.2014.03.014

Ke, W., \& Wei, K. K. (2008). Organizational culture and leadership in ERP implementation. Decision Support Systems, 45(2), 208-218. https://doi.org/10.1016/j.dss.2007.02.002

Kettinger, W. J., Grover, V., Guha, S., \& Segars, A. H. (1994). Strategic information systems revisited: A study in sustainability and performance. MIS Quarterly, 18(1), 31-58. https://doi.org/10.2307/249609

Kim, H., \& Ramkaran, R. (2003). Best practices in e-business process management: Extending a Reengineering framework. Toronto: York University. Retrieved June 25, 2003, from http://www.yorku. ca/hmkim/files/BPMJ-EBPM.pdf

Kirikkaleli, D., \& Ozun, A. (2019). Innovation capacity, business sophistication and macroeconomic stability: Empirical edvidence from OECD countries. Journal of Business Economics and Management, 20(2), 351-367. https://doi.org/10.3846/jbem.2019.9602 
Kleis, L., Chwelos, P., Ramirez, R. V., \& Cockburn, I. (2012). Information technology and intangible output: The impact of IT investment on innovation productivity. Information Systems Research, 23(1), 42-59. https://doi.org/10.1287/isre.1100.0338

Kling, R., \& Lamb, R. (2000). IT and organizational change in digital economies: A socio-technical approach. In B. Brynjolfsson \& E. Kahin, (Eds.), Understanding the digital economy - Data, tools and research (pp. 295-324). The MIT Press. https://b-ok.cc/book/952467/e34416

Ko, E., Kim, S. H., Kim, M., \& Woo, J. Y. (2008). Organizational characteristics and the CRM adoption process. Journal of Business Research, 61(1), 65-74. https://doi.org/10.1016/j.jbusres.2006.05.011

Kohli, R., \& Sherer, S. (2002). Measuring payoff of information technology investments: Research issues and guidelines. Communications of the Association for Information Systems, 9(14), 241-268. https://doi.org/10.17705/1CAIS.00914

Kyung-Kwon, H., \& Young-Gul, K. (2002). The critical success factors for ERP implementation: An organizational fit perspective. Information \& Management, 40(1), 25-40. https://doi.org/10.1016/S0378-7206(01)00134-3

Liang, H., \& Xue, Y. (2004). Coping with ERP-related contextual issues in SMEs: A vendor's perspective. Journal of Strategic Information Systems, 13(4), 399-415. https://doi.org/10.1016/j.jsis.2004.11.006

Liao, H., Wang, B., Li, B., \& Weyman-Jones, T. (2016). ICT as a general-purpose technology: The productivity of ICT in the United States revisited. Information Economics and Policy, 36, 10-25. https://doi.org/10.1016/j.infoecopol.2016.05.001

Markus, L., \& Tanis, C. (2000). The enterprise systems experience - From adoption to success. In R. Zmud (Ed.), Framing the domains of IT management: Projecting the future ... through the past (pp. 173-207). Pinnaflex Educational Resources inc.

Microsoft Corporation. (2008). Annual Report 2008. Microsoft Corporation, Seattle. Retrieved May 4, 2009, from https://www.microsoft.com/investor/reports/ar08/10k_dl_dow.html

Microsoft Corporation. (2015). Annual Report 2015. Microsoft Corporation, Seattle. https://www.microsoft.com/investor/reports/ar15/download-center/index.html

Microsoft Corporation. (2017). Annual Report 2017. Microsoft Corporation, Seattle. https://view.officeapps.live.com/op/view.aspx?src=https://c.s-microsoft.com/en-us/CMSFiles/2017_ Annual_Report.docx?version=fdf60a00-f415-bcd2-9b39-885a21c40164

Porter, M. E., \& Millar, V. E. (1985). How information gives you competitive advantage. Harvard Business Review, 63(4), 149-160.

Mithas, S., \& Rust, R. T. (2016). How information technology strategy and investments influence firm performance: Conjecture and empirical evidence. Mis Quarterly, 40(1), 223-245. https://doi.org/10.25300/MISQ/2016/40.1.10

Mittal, N., \& Nault, B. (2009). Investments in information technology: Indirect effects and information technology intensity. Information Systems Research, 20(1), 140-154.

Mohammad, A. Z. (2018). The role of technology, organization, and environment factors in enterprise resource planning implementation success in Jordan. International Business Research, 11(8), 48-65. https://doi.org/10.5539/ibr.v11n8p48

Mohanty, R. P., Agarwal, R., Choudhury, A. K., \& Tiwari, M. K. (2005). A fuzzy ANP-based approach to R\&D project selection: A case study. International Journal of Production Research, 43(24), 51995216. https://doi.org/10.1080/00207540500219031

Moon, Y. (2007). Enterprise Resource Planning (ERP): A review of the literature. Journal of Management and Enterprise Development, 4(2), 235-264. https://doi.org/10.1504/IJMED.2007.012679

Morton, N. A., \& Hu, Q. (2008). Implications of the fit between organizational structure and ERP: A structural contingency theory perspective. International Journal of Information Management, 28(5), 391-402. https://doi.org/10.1016/j.ijinfomgt.2008.01.008 
Neal, A., West, M., \& Patterson, M. (2000). An examination of interactions between organizational climate and human resource management practices in manufacturing organizations (Working paper No. RP 0003). Aston Business School Research Institute.

Neubert, M., \& Van der Krogt, A. (2018). Impact of business intelligence solutions on export performance of software firms in emerging economies. Technology Innovation Management Review, 8(9), 39-49. https://doi.org/10.22215/timreview/1185

OECD. (2004). The economic impact of ICT; measurements, evidence and implications. OECD.

Oracle Corporation. (2008). Oracle Corporation fiscal year 2008 form 10-K annual report. Redwood. Retrieved May 4, 2009, from http://www.oracle.com/corporate/investor_relations/earnings/10k-2008. pdf

Oracle Corporation. (2013). Oracle Corporation fiscal year 2013 form 10-K annual report. http://www.oracle.com/us/corporate/investor-relations/financials/fy2013-form-10k-1966521.pdf

Oracle Corporation. (2017). Oracle Corporation fiscal year 2013 form 10-K annual report. http://www.annualreports.com/Company/oracle-corporation

Ozgur, C., \& Strasser, S. (2004). A study of the statistical inference criteria: Can the authors agree on when to use $\mathrm{Z}$ versus t? The Decision Sciences Journal of Innovative Education, 2(2), 177-192. https://doi.org/10.1111/j.1540-4609.2004.00043.x

Paul, D. (1990). The dynamo and the computer: An historical perspective on the modern productivity paradox. The American Economic Review, 80(2), 355-361.

Podobnik, Š. (2004). Korupcija pri javnih naročilih [Corruption in Public Tenders]. University of Ljubljana.

Poku, K., \& Vlosky, R. P. (2002). A model of the impact of corporate culture on Information Technology adoption (Louisiana Forest Products Laboratory Working Paper \#57). https://www.lsuagcenter. com/ /media/system/7/5/b/c/75bc161651b6eb63a8b7b90cb8c1da12/wp57.pdf

Potluri, R. M., \& Vajjhala, N. R. (2018). A study on application of web 3.0 technologies in small and medium enterprises of India. The Journal of Asian Finance, Economics and Business, 5(2), 73-79. https://doi.org/10.13106/jafeb.2018.vol5.no2.73

Rezende da Costa, P., Silva Braga Junior, S., Silveira Porto, G., \& Martinez, M. P. (2018). Relational capability and strategic alliance portfolio configuration: A study of Brazilian technology firms. International Journal of Emerging Markets, 13(5), 1026-1049. https://doi.org/10.1108/IJoEM-07-2016-0167

Romero, I., \& Martínez-Román, J. A. (2015). Determinants of technology adoption in the retail trade industry - the case of SMEs in Spain. Amfiteatru Economic Journal, 17(39), 646-660.

SAP AG (2004). Sap annual report 2004. Investing in Success. Walldorf. http://www.annualreports.com/HostedData/AnnualReportArchive/s/NYSE_SAP_2004.pdf

SAP AG. (2008). Sap annual report 2008 on form 20-F. Sap Corporation, Palo Alto. Retrieved May 4, 2009, from http://www.sap.com/germany/about/investor/pdf/GB2008_onForm20F.pdf

SAP SE. (2015). Sap annual report 2015. Sap Corporation, Walldorf. http://go.sap.com/docs/download/investors/2015/sap-2015-annual-report.pdf

Saravanan, R., \& Sundar, C. (2015). Derivation and validation of a conceptual model for ERP implementation success factors - An Indian context. Journal of Theoretical \& Applied Information Technology, 78(1), 132-146.

Scott, J., \& Vessey, I. (2002). Managing risks in enterprise systems implementations. Communications of the ACM, 45(4), 74-81. https://doi.org/10.1145/505248.505249

Seethamraju, R. (2015). Adoption of Software as a Service (SaaS) Enterprise Resource Planning (ERP) Systems in Small and Medium Sized Enterprises (SMEs). Information Systems Frontiers, 17, 475492. https://doi.org/10.1007/s10796-014-9506-5 
Shafique, M. N., Raudeliūnienė, J., Davidaviciene, V., \& Penčik, J. (2019). Acceptance of intelligent ticketing systems in developing countries. Engineering Economics, 30(4), 451-460. https://doi.org/10.5755/j01.ee.30.4.20941

Sharma, S. (1996). Applied multivariate techniques. John Wiley and Sons.

Shaul, L., \& Tauber, D. (2013). Critical success factors in enterprise resource planning systems: Review of the last decade. ACM Computing Surveys, 45(4), 1-39. https://doi.org/10.1145/2501654.2501669

Slovenian Press Agency. (2011). Javna naročila leglo korupcije [Public tenders are the root of corruption]. Slovenian Press Agency. http://www.zurnal24.si/javna-narocila-leglo-korupcije-clanek-79519

Soh, C., Kien, S. S., \& Tay-Yap, J. (2000). Cultural fits and misfits: Is ERP a universal solution? Communications of the ACM, 43(3), 47-51. https://doi.org/10.1145/332051.332070

Sudhaman, P., \& Thangavel, C. (2015). Efficiency analysis of ERP projects - software quality perspective. International Journal of Project Management, 33(4), 961-970. https://doi.org/10.1016/j.ijproman.2014.10.011

Swanson, E. B. (1994). Information systems innovation among organizations. Management Science, 40(9), 1069-1092. https://doi.org/10.1287/mnsc.40.9.1069

Taştan, H., \& Gönel, F. (2020). ICT labor, software usage, and productivity: Firm-level evidence from Turkey. Journal of Productivity Analysis, 53, 265-285. https://doi.org/10.1007/s11123-020-00573-X

Temur, G. T., \& Bolat, B. (2018). A robust MCDM approach for ERP system selection under uncertain environment based on worst case scenario. Journal of Enterprise Information Management, 31(3), 405-425. https://doi.org/10.1108/JEIM-12-2017-0175

Yusuf, Y., Gunasekaran, A., \& Abthorpe, M. (2004). Enterprise information systems project implementation: A case study of ERP in Rolls-Royce. International Journal of Production Economics, 87(3), 251-266. https://doi.org/10.1016/j.ijpe.2003.10.004

Zeng, Y. R., Wang, L., \& Xu, X. H. (2017). An integrated model to select an ERP system for Chinese small-and medium-sized enterprise under uncertainty. Technological and Economic Development of Economy, 23(1), 38-58. https://doi.org/10.3846/20294913.2015.1072748 